\title{
Disease in sea urchins Strongylocentrotus purpuratus: experimental infection and bacterial virulence
}

\author{
Kay W. Gilles* \& John S. Pearse \\ Institute of Marine Sciences and Department of Biology, University of California, Santa Cruz, California 95064, USA
}

\begin{abstract}
Naturally occurring diseased sea urchins Strongylocentrotus purpuratus were present at low incidences in the Monterey Bay area, California (USA); they were used to examine the basic characteristics of disease in sea urchins. Bacteriological sampling of lesion material revealed the presence of 14 bacterial strains including Vibrio, Aeromonas, Flavobacterium and Pseudomonas. The 14 isolates were characterized and extensively tested for pathogenic potential. Of these bacterial isolates, only those of Vibrio anguillarum and Aeromonas salmonicida were able to initiate lesion formation in the laboratory. Experimental lesions induced in the laboratory had similar characteristics and progression of events as those observed during naturally occurring spontaneous infections. Experimental infectivity tests determined that a stress such as injury was necessary for the formation of a characteristic lesion.
\end{abstract}

\section{INTRODUCTION}

Diseases have caused mortalities in many natural and captive populations of echinoderms (for review see Jangoux 1984). Most notable have been dramatic mass mortalities of sea urchins in a variety of localities (California: Johnson 1971, Pearse et al. 1977; Mediterranean: Boudouresque et al. 1981, Höbaus et al. 1981; Caribbean and western tropical Atlantic: Lessios et al. 1983, 1984a, b; Nova Scotia: Miller \& Colodey 1983, Scheibling 1984, Scheibling \& Stephenson 1984). Lessios et al. (1984a) suggested that a water-borne pathogen was involved, and laboratory and field experiments by Miller (1985) support that hypothesis. A pathogenic amoeba, Paramoeba sp., that apparently destroys muscle and connective tissue, may be the responsible pathogen, at least for the mass mortalities in Nova Scotia (Jones et al. 1985).

Echinoids dying in the reported mass mortalities often posses characteristic lesions on their tests. These lesions, described by Johnson (1971), Maes \& Jangoux (1984), and Maes et al. (1985), involve a central necro-

\footnotetext{
- Present address: Department of Neurology, HSE-781, University of California Medical Center, San Francisco, California 94143 , USA
}

tic region of disorganized skeletal tissue surrounded by a ring of swollen tissue. Because the necrotic areas are free of spines and appear denuded, Maes \& Jangoux (1984) termed the condition the 'bald-sea-urchin' disease. The lesions can grow until they perforate the test and the animal dies, presumably from internal infection. However, in many cases, growth of the lesion is checked, the animals recover, and the affected areas of the test regenerate (Gilles unpubl.).

In addition to being found in sea urchins during episodes of mass mortalities, lesions have been noted occasionally on individuals in populations of otherwise healthy animals (Mortensen \& Rosevinge 1934, Pearse et al. 1977, Maes \& Jangoux 1984, Scheibling 1984). These observations suggest that the pathogens responsible for lesion formation are normally present.

Diverse microorganisms have been observed in the necrotic area of the lesions, including masses of bacteria, algae, ciliates, nematodes, and microarthropods (Johnson 1971, Maes et al. 1985). Although Mortensen \& Rosevinge (1934) suggested the pathogen might be a cyanobacterium, Maes \& Jangoux $(1984,1985)$ isolated from lesions non-photosynthetic bacteria capable of causing lesions when inoculated onto artificially injured test areas of healthy sea urchins.

To understand further the pathogens responsible for 
the lesions on diseased sea urchins, we isolated and characterized bacteria from lesions found on diseased individuals collected in field populations of mostly undiseased animals. The bacterial isolates were used in a variety of infectivity experiments to determine their disease-causing ability, and whether any might be capable of causing mass mortalities.

\section{MATERIALS AND METHODS}

Sea urchins. Healthy Strongylocentrotus purpuratus were collected at low tide from Pigeon Point, San Mateo county (Lat. $37^{\circ} 06^{\prime} 25^{\prime \prime} \mathrm{N}$, Long. 122 $19^{\prime} 30^{\prime \prime} \mathrm{W}$ ), California (USA) and transported immediately to the laboratory. They were maintained in 20 gallon (75.7 l) glass aquaria supplied with running, sand-filtered, aerated sea water at 15 to $16^{\circ} \mathrm{C}$ and were fed weekly with pieces of giant kelp Macrocystis pyrifera. Individuals of 4 to $6 \mathrm{~cm}$ diameter were used in these experiments. During 1981-1982, monthly field surveys of intertidal and subtidal areas were conducted at Pigeon Point, Davenport Landing, Point Santa Cruz, Hopkins Marine Station, and Stillwater Cove (Carmel Bay) to locate and collect diseased sea urchins. Diseased individuals with lesions similar to those described by Johnson (1971) and Pearse et al. (1977) were found, albeit in low incidences of about 1 per 1000 individuals, as reported by Yellin et al. (1977). These diseased individuals, found among healthy sea urchins, were collected and examined immediately for causative agents of the disease (see below). Diseased sea urchins were also used for experimental infectivity tests in the laboratory (see below).

Histological examination. Diseased sea urchins were examined using a dissecting microscope and lesion material was examined using a Zeiss phase contrast microscope. Tissues for histological examination included spines, test, gut, esophagus, axial organ, gonads, tube feet and pedicellaria. The tissues were fixed for $48 \mathrm{~h}$ in $10 \%$ formalin-sea water, $\mathrm{pH} 7.5$, decalcified for $4 \mathrm{~d}$ in a $10 \%$ EDTA solution, dehydrated in a series of ethyl alcohol dilutions (70, 80, 90 and $95 \%$ ) using 2 changes of 30 min each and embedded in 2-hydroxyethyl methacrylate (Sorvall Embedding Medium, Du Pont Co.). Thick sections (2 mm) were cut, stained with $1 \%$ toluidine blue $O$, and examined with a Zeiss phase contrast microscope.

Bacterial isolation. Media: The artificial marine salts (AMS) used in this study consisted of $445 \mathrm{mM} \mathrm{NaCl}$, $49 \mathrm{mM} \mathrm{MgSO} \cdot 7 \mathrm{H}_{2} \mathrm{O}, 9 \mathrm{mM} \mathrm{KCl}$, and $10 \mathrm{mM} \mathrm{CaCl}_{2}$. $2 \mathrm{H}_{2} \mathrm{O}$ (Lara 1970). A semi-solid nutrient medium (AMS-NA) composed of nutrient agar suspended in AMS and a liquid medium (AMS-NB) consisting of dehydrated nutrient broth (Difco) suspended in AMS were routinely used. Yeast extract peptone (YEP) con- tained $0.1 \%$ yeast extract (Difco) and $0.5 \%$ peptone (Difco) suspended in AMS and solidified with $1.5 \%$ agar. All media used in identification and classification of cultures were prepared with AMS except tests for $\mathrm{Na}^{+}$requirement which used distilled water in place of AMS. Sea water, used to sample diseased sea urchins, was sterilized by filtering with 0.45 and $0.22 \mu \mathrm{m}$ Millipore filters and steamed in an autoclave for $2 \mathrm{~h}$.

Source of isolates: All diseased sea urchins found (about 100) were rinsed with a $20 \mathrm{~s}$ stream of sterile sea water and sampled in the field. Sterile cotton-tipped applicator sticks were used to swab lesions of diseased individuals. The sticks were then used to inoculate AMS-NA plates by streaking the surface. The inoculated plates were immediately brought to the laboratory, incubated at $22^{\circ} \mathrm{C}$ for 1 to $4 \mathrm{~d}$, and observed for the appearance of isolated colonies. Such colonies were purified by restreaking 3 successive times on homologous medium before beginning the characterization program.

Preservation of cultures: Bacterial isolates were maintained at $4{ }^{\circ} \mathrm{C}$ on YEP slants overlaid with sterile glycerol. After monthly transfers, the stock cultures were allowed to grow at $22{ }^{\circ} \mathrm{C}$ for 1 to $2 \mathrm{~d}$ and again placed at $4{ }^{\circ} \mathrm{C}$. When required, stored cultures were warmed to room temperature, resuspended and cultured in AMS-NB medium for characterization experiments and for use as inocula to infect healthy individuals.

Bacterial characterization: All biochemical, cellular and cultural morphological tests, unless otherwise stated, were incubated at $22^{\circ} \mathrm{C}$. Each pure culture was tested at least twice, and, in nearly all cases, repeated a minimum of 3 times by a number of determinative procedures listed in Table 1.

Sodium requirement: All isolates were tested for their ability to grow on NA media containing $0,0.5,2.5$ and $3 \% \mathrm{NaCl}$ (Sakazake \& Balows 1981). Cells $(0.1 \mathrm{ml})$ from late logarithmic phase cultures were inoculated onto plates containing the media and incubated for $48 \mathrm{~h}$ at 12 and $22{ }^{\circ} \mathrm{C}$.

Temperature sensitivity: Growth at different temperatures was recorded in AMS-NA plates inoculated and incubated at 12,22 and $37^{\circ} \mathrm{C}$. Observations of growth were repeated daily for $4 \mathrm{~d}$ and up to $2 \mathrm{wk}$ for cultures incubated at $12{ }^{\circ} \mathrm{C}$.

Sensitivity to vibriostatic agent 0/129: Sensitivity to 0/129 (2,4 diamino-6,diisopropyl pteridine) (Sigma Chemical Co., St. Louis, Missouri) was determined using a disc method in which $6 \mathrm{~mm}$ discs contained a concentration of $20 \mu \mathrm{g}$ of the agent (Furniss et al. 1978, Gerhardt et al. 1981). Control plates without 0/129 and experimental plates were incubated $24 \mathrm{~h}$ before reading sensitivities. 
Table 1. Characteristics ${ }^{*}$ of bacteria isolated from lesions of diseased Strongylocentrotus purpuratus

\begin{tabular}{|c|c|c|c|c|c|c|c|c|c|c|c|c|c|c|}
\hline \multirow[t]{2}{*}{ Characteristics } & \multicolumn{3}{|c|}{$\begin{array}{c}\text { Vibrio } \\
\text { anguillarum }\end{array}$} & \multicolumn{2}{|c|}{$\begin{array}{l}\text { Aeromonas } \\
\text { salmonicida }\end{array}$} & \multicolumn{8}{|c|}{ Flavobacterium spp. } & \multirow{2}{*}{$\begin{array}{c}\text { Pseudo- } \\
\text { monas } \\
1\end{array}$} \\
\hline & 1 & 2 & 3 & 1 & 2 & 1 & 2 & 3 & 4 & 5 & 6 & 7 & 8 & \\
\hline Gram stain & - & - & - & - & - & - & - & - & - & - & - & - & - & - \\
\hline Pigment $\cdots$ & - & - & - & d & $\mathrm{d}$ & $\mathrm{br}$ & $y$ & yo & $\mathrm{t}$ & o & $\mathrm{y}$ & $\mathrm{y}$ & $\mathrm{y}$ & $\mathrm{p}$ \\
\hline Motility & + & + & + & - & - & - & - & - & - & - & - & - & - & + \\
\hline Flagella (polar) & + & + & + & - & - & - & - & - & - & - & - & - & - & + \\
\hline Plasmid DNA & - & + & + & + & + & - & + & - & $\mathrm{U}$ & - & + & + & + & - \\
\hline \multicolumn{15}{|l|}{ Temperature sensitivity: } \\
\hline $37^{\circ} \mathrm{C}$ & - & - & - & - & - & - & - & - & - & - & - & + & - & - \\
\hline $22^{\circ} \mathrm{C}$ & + & + & + & + & + & + & + & + & + & + & + & + & + & + \\
\hline $12^{\circ} \mathrm{C}$ & + & + & + & + & + & + & + & + & + & + & + & + & + & + \\
\hline Glucose metabolism & $\mathrm{F}$ & $\mathrm{F}$ & $\mathrm{F}$ & $\mathrm{F}$ & $\mathrm{F}$ & $\mathrm{O}$ & $\mathrm{O}$ & $\mathrm{O}$ & $\mathrm{O}$ & $\mathrm{O}$ & $\mathrm{O}$ & $\mathrm{O}$ & $\mathrm{O}$ & $\mathrm{O}$ \\
\hline Gas from glucose & - & - & - & + & + & - & - & - & - & - & - & - & - & - \\
\hline \multicolumn{15}{|l|}{ Carbohydrate utilization: } \\
\hline Amygdalin & + & + & + & - & + & - & - & - & - & - & - & - & - & - \\
\hline Maltose & + & + & + & + & + & - & + & - & - & - & - & + & - & + \\
\hline Mannitol & + & + & + & + & + & - & + & - & - & - & - & - & - & + \\
\hline Dextrose & + & + & + & - & + & - & - & - & - & - & - & - & - & - \\
\hline Saccharose & - & + & + & - & - & - & + & - & - & - & - & + & - & - \\
\hline Sucrose & + & + & + & - & - & - & - & - & - & - & - & - & - & + \\
\hline Arabinose & - & - & + & - & - & - & + & + & - & - & - & - & - & - \\
\hline Melibiose & + & + & - & - & - & - & - & - & - & - & - & - & - & - \\
\hline Sorbitol & + & - & - & - & - & - & - & - & - & - & - & - & - & - \\
\hline Inositol & - & - & - & - & - & - & - & - & - & - & - & - & - & + \\
\hline Lactose & - & - & - & - & - & - & - & - & - & - & - & - & - & - \\
\hline Rhamnose & - & - & - & - & - & - & - & - & - & - & - & - & - & - \\
\hline \multicolumn{15}{|l|}{ Antibiotic sensitivity: } \\
\hline Chloramphenicol & + & + & + & + & + & + & + & + & + & + & + & + & + & - \\
\hline Polymyxin B & + & + & + & + & + & + & + & - & + & + & + & + & + & - \\
\hline Ampicillin & - & + & + & + & - & + & + & + & + & + & - & + & + & - \\
\hline Naladixic acid & - & - & - & + & - & + & + & + & + & + & + & - & + & - \\
\hline Penicillin & - & - & - & + & - & - & - & + & + & - & + & + & - & - \\
\hline Erythromycin & - & - & - & - & - & + & - & + & + & + & - & + & - & - \\
\hline Tetracycline & + & + & + & + & - & - & - & - & - & + & - & - & - & - \\
\hline Streptomycin & - & + & - & + & - & - & + & - & - & - & - & - & - & - \\
\hline \multicolumn{15}{|l|}{ Biochemical tests: } \\
\hline Gelatin liquefaction & + & + & + & + & + & + & + & + & - & + & + & - & - & + \\
\hline $\mathrm{H}_{2} \mathrm{~S}$ production & - & - & - & - & - & - & - & - & - & - & - & - & - & - \\
\hline Nitrate reduction & - & + & + & + & + & - & - & - & - & - & - & - & - & - \\
\hline Arginine dihydrolase & + & + & + & + & + & - & - & - & - & - & - & - & - & - \\
\hline Lysine decarboxylase & - & - & - & - & - & - & - & - & - & - & - & - & - & - \\
\hline Ornithine decarboxylase & - & - & - & - & - & - & - & - & - & - & - & - & - & - \\
\hline Vogues-Proskauer & - & - & - & - & - & - & - & - & - & - & - & - & - & - \\
\hline Indole & - & + & + & + & + & - & - & - & - & - & - & - & - & - \\
\hline Urease & - & - & - & - & - & - & - & - & - & - & - & - & - & - \\
\hline Citrate & - & - & - & - & - & - & - & - & - & - & - & - & - & - \\
\hline Oxidase & + & + & + & + & + & + & + & + & + & + & + & + & + & + \\
\hline Catalase & + & + & + & + & + & + & + & + & + & + & + & + & + & + \\
\hline ONPG & + & + & + & + & + & + & - & + & - & - & - & + & - & + \\
\hline Tryptophane deaminase & - & - & - & - & - & - & - & - & - & - & - & - & - & - \\
\hline Salt requirement $(0.5 \%)$ & + & + & + & + & + & + & + & + & + & + & + & + & + & - \\
\hline Starch hydrolysis & + & + & + & + & + & + & - & + & + & + & + & + & + & + \\
\hline Chitinase & - & - & - & - & - & - & - & - & - & - & - & - & - & - \\
\hline Lipase & + & + & + & + & + & + & + & + & + & + & + & + & + & - \\
\hline Protease & + & + & + & + & + & + & - & + & - & + & - & + & - & + \\
\hline TSBS & + & + & + & + & + & - & - & - & - & - & - & - & - & - \\
\hline Vibriostat $0 / 129$ & + & + & + & - & - & - & - & - & - & - & - & - & - & - \\
\hline Bioluminescence & - & - & - & - & - & - & - & - & - & - & - & - & - & - \\
\hline
\end{tabular}


Oxidase: After growth on AMS-NA, reaction of the isolates was examined using a $1 \%$ aqueous solution of the tetramethyl-p-phenylenediamine- $\mathrm{HCl}$ reagent by transferring each culture with sterile wood sticks to reagent-soaked filter paper according to the method of Kovacs (1956).

Growth characteristics: Pigmentation and colonial characteristics were established for cultures grown on solid (AMS-NA) and liquid (AMS-NB) media for 24 to $48 \mathrm{~h}$. Soluble pigment production of presumptive Aeromonas isolates was recorded after growth on AMS-NA supplemented with $0.1 \%$ tyrosine (Sakazake \& Balows 1981). Growth on thiosulfate-citrate-bile salts-sucrose (TCBS) agar (Difco) was determined and the capability to bioluminesce was tested according to the method of Ruby \& Nealson (1978).

Motility, morphology and flagellation: Cell motility and morphology was determined from exponential phase cultures grown on AMS-NA solid media and in AMS-NB liquid media by examination with a Zeiss phase contrast microscope as well as growth characteristics on motility media. Observation of morphology was repeated after Gram reaction. Gram reaction was performed on late exponential cultures (Gerhardt et al. 1981) and each isolate was examined for flagella using the method of Mayfield \& Inniss (1977). Additionally, each isolate was negatively stained according to the methods described by Koga et al. (1982), Chow \& Rouf (1983) and Allen \& Baumann (1971), and each isolate was observed in a Siemens $1 \mathrm{~A}$ transmission electron microscope at an accelerating voltage of $60 \mathrm{kV}$.

Carbohydrate utilization: Carbohydrate utilization and producttion of acid and gas were determined by inoculation of tubes of Bacto Phenol Red broth base (Difco) containing AMS and $1 \%$ carbohydrate (Sigma) and an inverted inner vial. Thirteen carbohydrates were tested. Each culture was incubated at 12 and $22^{\circ} \mathrm{C}$, and examined at $1,7,14$ and $28 \mathrm{~d}$ for acid and gas production.

Enzyme production: Amylase production was detected according to the method of Gerhardt et al. (1981) by observation of starch hydrolysis on plates flooded with Gram's iodine solution. In an effort to establish whether isolates could produce chitinase, cultures were inoculated onto solid media containing AMS, $2 \%$ chitin and $1.5 \%$ agar, and observed at intervals up to $40 \mathrm{~d}$ for clearing around colonies (Lear 1963). Gelatinase production was detected by observation of gelatin (Sigma) tubes for liquefaction after $7 \mathrm{~d}$ (Bradshaw 1973). Lipase production was determined following the method of Gerhardt et al. (1981), using Tween 80 (Sigma) prepared with AMS by observing a precipitate of calcium oleate surrounding colonies after 2 to $6 \mathrm{~d}$ incubation. Protease production was determined after $7 \mathrm{~d}$ incubation, by observation of clear areas around colonies grown on milk agar (Sizemore \& Stevenson 1970).

Plasmid analysis: Plasmids were detected in the isolates using 3 plasmid isolation techniques (Gilles 1984). After agarose gel electrophoresis, plasmid bands were visualized on an Ultra-violet Transilluminator (Model TM-15, Ultra-violet Products Inc., San Gabriel, Calif.) and photographed using a Polaroid MP-3 camera on type 667 Film (Polaroid Corp., Cambridge, Mass.).

Antibiotic sensitivity: Sensitivity to antibiotics was determined by disk tests (Bacto-sensitivity disks, Difco) and evaluated on the basis of zone diameter interpretive standards in the manufacturers instructions. The following drug susceptibility testing disks were used: chloramphenicol $(30 \mu \mathrm{g})$, polymyxin B (300 U), ampicillin $(10 \mu \mathrm{g})$, naladixic acid $(30 \mu \mathrm{g})$, penicillin $(10 \mathrm{U})$, erythromycin $(15 \mu \mathrm{g})$, tetracycline $(30 \mu \mathrm{g})$ and streptomycin $(10 \mu \mathrm{g})$.

Rapid multitest system: The API 20E diagnostic kit (Analytab Products, Plainview, N.Y.) was used with the salinity of the suspending AMS fluid adjusted to $20 \%$ (MacDonell et al. 1982). Colonies for inocula were late logarithmic phase cultures suspended in the dilute sterile AMS solution. Aliquots of this suspension were placed in each test microtubule, incubated $24 \mathrm{~h}$ at $22{ }^{\circ} \mathrm{C}$, and results interpreted according to the manufacturers methodology.

Experimental infection. Sea urchins of ca $4 \mathrm{~cm}$ diameter were acclimated for $1 \mathrm{wk}$ in individual $400 \mathrm{ml}$ plastic containers supplied with running filtered sea water at ambient temperature $\left(14\right.$ to $\left.16^{\circ} \mathrm{C}\right)$, in the laboratory sea table. They were fed kelp twice during the week before experimentation. All manipulations were performed at room temperature (ca $19^{\circ} \mathrm{C}$ ) and urchins were returned immediately to the running sea water table unless otherwise stated. All sea urchins used in these experiments were washed by holding them with sterile forceps and running a stream of sterile sea water $(0.22 \mu \mathrm{m}$ Millipore filtered) over them for $20 \mathrm{~s}$. They were examined daily for $2 \mathrm{wk}$ and weekly thereafter for $3 \mathrm{mo}$.

Experiments to initiate disease in healthy sea urchins included: (1) transfer of lesion material from sick to healthy individuals; (2) close contact between diseased and healthy individuals; (3) inoculation of bacterial isolates directly onto the sea urchin epithelium. To determine whether a stress such as injury was necessary for lesion formation, experimental sea urchins were abraded mechanically using a sterile scalpel blade prior to their exposure to infectious material. Abrasions of $3 \times 6 \mathrm{~mm}$ were made on the aboral surface of the urchin using the madreporite as a reference point.

Lesion transfer: Lesion material was lifted from diseased sea urchins using a sterile applicator stick and 

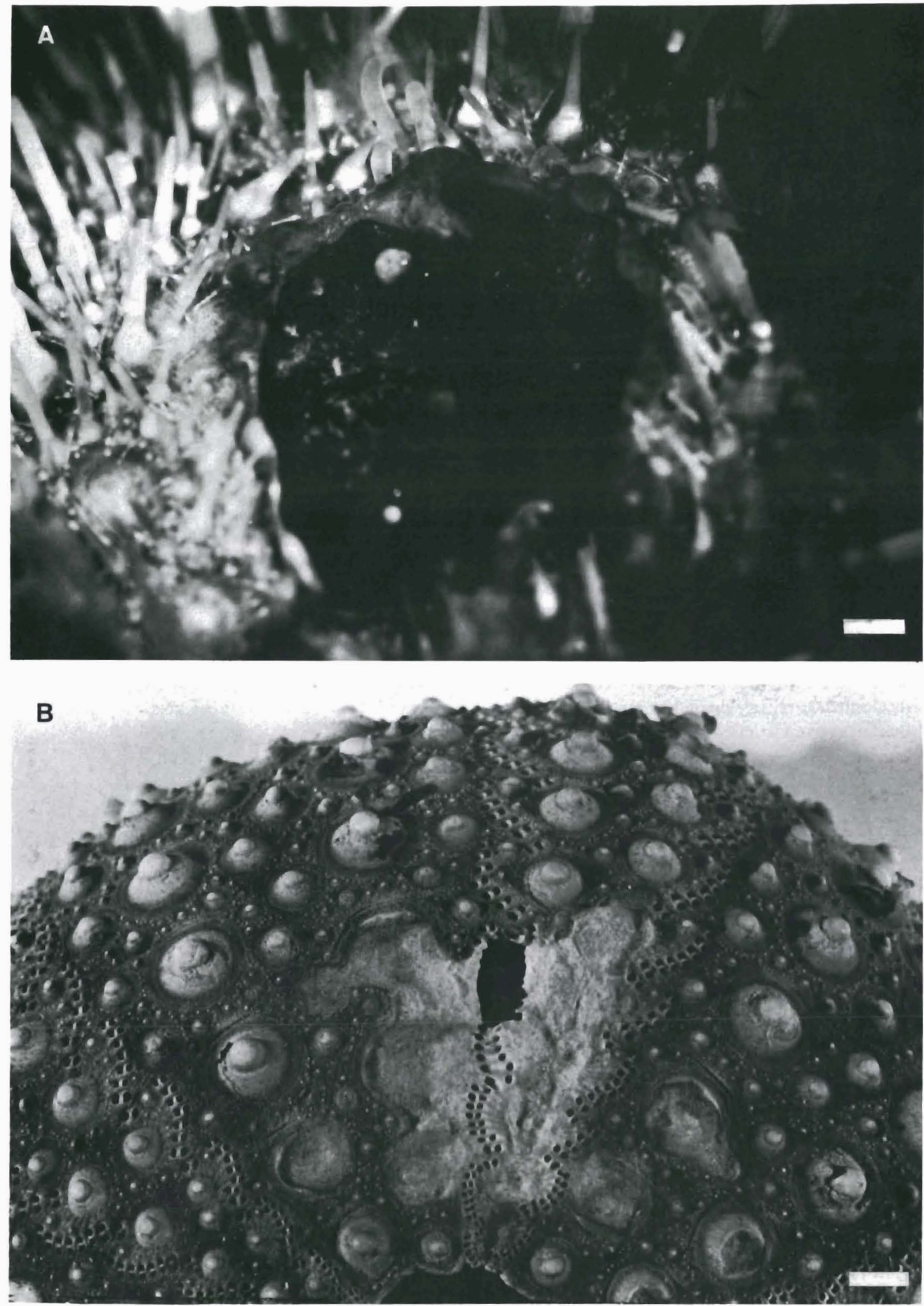

Fig. 1. Strongylocentrotus purpuratus. (A) Characteristic appearance of a lesion on a diseased individual showing the dark, friable material in the center surrounded by a swollen, shiny membrane enclosed outer part. (B) Photograph of a dried test of a diseased urchin (after death) showing a lesion area which had eroded and flaked away. Markers represent $0.4 \mu \mathrm{m}$ 
placed on the epithelial surface of healthy, nonabraded and healthy, mechanically abraded individuals. Control urchins were also abraded but no lesion material was placed on the abrasions. All groups contained 5 individuals each. The sea urchins were placed in individual $400 \mathrm{ml}$ plastic containers set in the sea table and supplied with running sea water.

Close contact: Experimental groups consisted of: (1) diseased urchins placed in close contact with healthy, mechanically abraded individuals, and (2) diseased urchins placed with healthy, non-abraded individuals. Control groups were: (1) healthy, mechanically abraded urchins together; (2) healthy, non-abraded urchins together. Pairs were placed together in $400 \mathrm{ml}$ plastic containers set in the sea table and supplied with running sea water.

Bacterial virulence: Pure bacterial cultures were used as an inoculum applied directly onto the sea urchin surface epithelium. Fourteen cultures were prepared by growing each test organism on AMS-NA at $22^{\circ} \mathrm{C}$. A $3 \mathrm{~mm}$ colony was picked with a sterile wood applicator stick and placed directly on the epithelial surface of mechanically abraded and intact individuals. Inoculated sea urchins were wrapped in wet newspapers, incubated at $20^{\circ} \mathrm{C}$ for $1 \mathrm{~h}$, and returned to $400 \mathrm{ml}$ plastic containers in the sea table. Groups of 7 were abraded and inoculated for each isolate; in addition, groups of 7 individuals were inoculated but not abraded. Control urchins were abraded but not inoculated. Bacteria were recovered from lesion material using the methods described. Colonies, resembling the Vibrio and Aeromonas isolates used as inocula, were confirmed by Gram staining, colonial morphology on solid media, TCBS and $1 \%$ tyrosine media, the oxidase test, 0/129 and arginine, lysine and ornithine reactions and test results using the API 20E diagnostic kit system (Gilles 1984).

\section{RESULTS}

\section{Disease characteristics}

Fig. $1 \mathrm{~A}$ shows the characteristic features of spine loss and lesion formation in diseased sea urchins. The central area of the lesion developed a loosely aggregated, dark friable material which was surrounded by a swollen area as noted by Johnson (1971), Maes \& Jangoux (1984) and Maes et al. (1985). Examination by phase microscopy of the dark friable material revealed the variety of microorganisms including ciliates, copepods, amphipods, nematodes and bacteria as observed in Fig. 2. No amoebae or fungi were seen. Examination of the swollen area indicated prominent red granule and vibratile-like cells normally found in the coelomic fluid of the sea urchin; however, this swollen area was
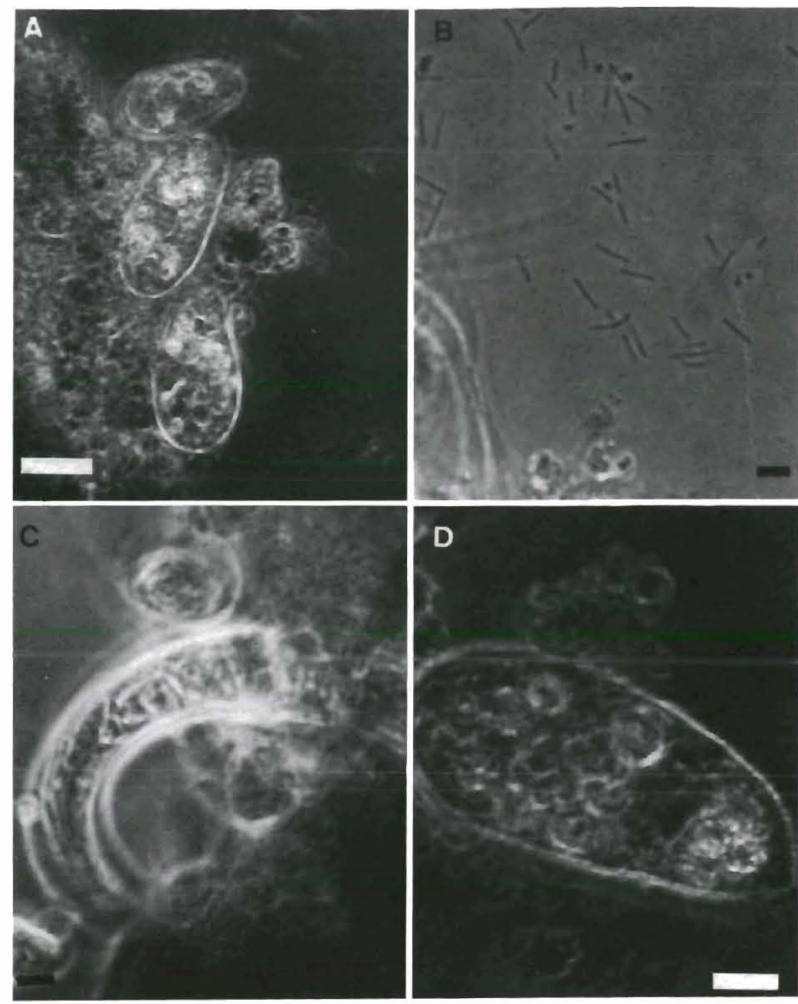

Fig. 2. Variety of microorganisms contained in the friable lesion material from diseased urchins, observed using phase contrast microscopy. (A) Ciliates (marker: $10 \mu \mathrm{m}$ ); (B) Bacteria (marker: $2 \mu \mathrm{m}$ ); (C) Nematode (marker: $2 \mu \mathrm{m}$ ); (D) Ciliate (marker: $3.1 \mu \mathrm{m}$ )

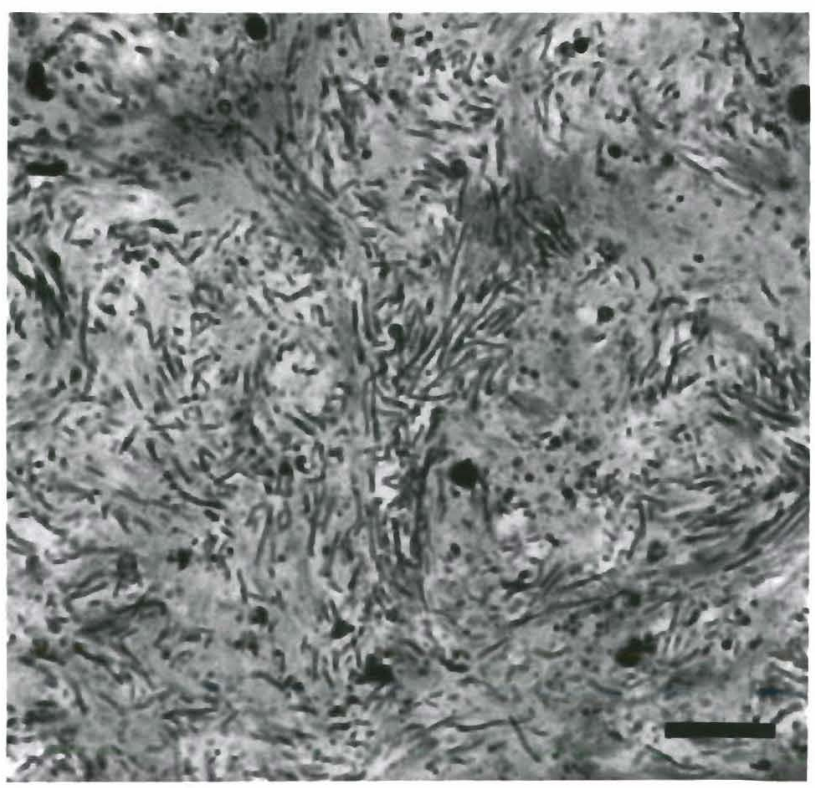

Fig. 3. Strongylocentrotus purpuratus. Thick section of tissue surrounding the base of the spines of diseased individuals, showing massive bacterial infestation in muscle and connective tissue. Marker: $5 \mu \mathrm{m}$ 
Table 2. Strongylocentrotus purpuratus. Results of transfer of lesion material from diseased to healthy individuals

\begin{tabular}{|c|c|c|c|c|}
\hline \multirow[t]{2}{*}{ Group } & \multirow{2}{*}{$\begin{array}{l}\text { No. of } \\
\text { urchins }\end{array}$} & \multicolumn{3}{|c|}{ Lesion development } \\
\hline & & $24 \mathrm{~h}$ & $2 \mathrm{~d}$ & $2 \mathrm{wk}$ \\
\hline \multicolumn{5}{|l|}{$\begin{array}{l}\text { Experimental: lesion material placed on } \\
\text { healthy urchins }\end{array}$} \\
\hline (1) Epithelium mechanically abraded & 5 & $\begin{array}{l}\text { Characteristic } \\
\text { lesion formed }\end{array}$ & $\begin{array}{l}\text { Progression similar } \\
\text { to natural lesions }\end{array}$ & Bare test exposed \\
\hline (2) Epithelium not abraded & 5 & $\begin{array}{l}\text { No lesion formed, } \\
\text { 'excretion' } \\
\text { observed }\end{array}$ & Same as at $24 \mathrm{~h}$ & $\begin{array}{l}\text { No evidence of } \\
\text { lesion formation }\end{array}$ \\
\hline $\begin{array}{l}\text { Control: no lesion material added } \\
\text { (3) Epithelium mechanically abraded }\end{array}$ & 5 & Small red clot & $\begin{array}{l}\text { Regeneration of } \\
\text { tissues }\end{array}$ & Complete healing \\
\hline
\end{tabular}

not infested with microorganisms. Examination of histological thick sections revealed massive bacterial invasion of the tissue around the base of the spines (Fig. 3). Progression of the disease resulted in erosion and flaking of the test (Fig. $1 \mathrm{~B}$ ). Other characteristics associated with diseased sea urchins included: edema, weak tube feet adherence, peeling epithelium and impaired ability of the urchin to right itself.

Internal changes observed in diseased sea urchins

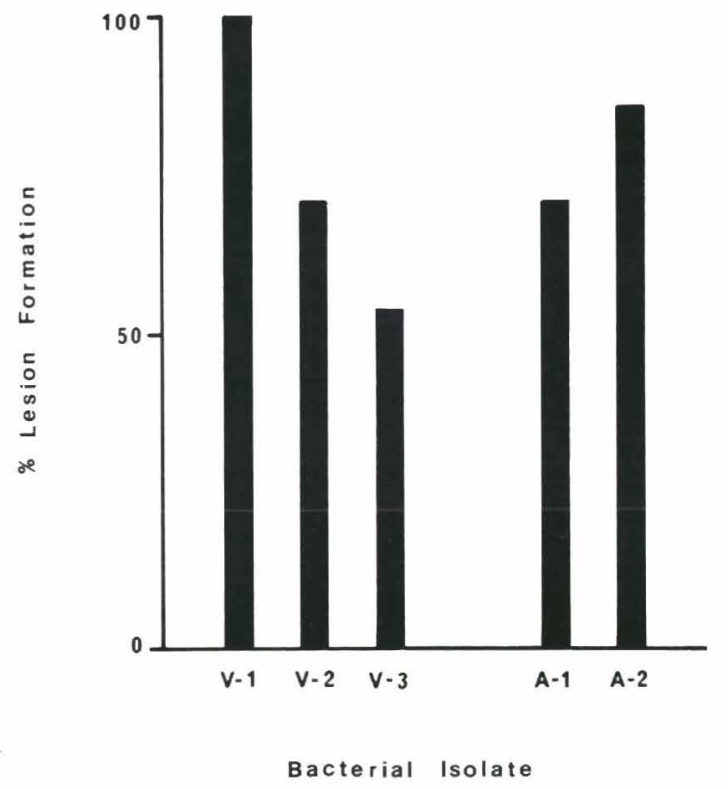

Fig. 4. Percent lesion formation by the 3 isolates of Vibrio anguillarum (V-1, V-2, V-3) and the 2 isolates of Aeromonas salmonicida (A-1, A-2) obtained from lesions on diseased Strongylocentrotus purpuratus. Lesions developed after an inoculum (see text) was placed onto the mechanically abraded epithelial surface of the urchin. Seven mechanically abraded and 7 .intact urchins per bacterial isolate were tested. None of the urchins with intact epithelium developed lesions when inoculated with these isolates included a massive increase of cell clumping in the circulation, phagocytosis, and excretion by constricting off spheroids (Höbaus 1979) from gill structures, tube feet and other external surfaces.

\section{Bacterial isolation}

A total of 14 strains of bacteria was isolated and purified from lesions on all diseased sea urchins collected; on the basis of morphological, physiological and biochemical properties given in Table 1, they were designated as 3 strains of Vibrio anguillarum, 2 strains of Aeromonas salmonicida, 8 strains of Flavobacterium, and 1 strain of Pseudomonas.

\section{Experimental infection}

Lesion transfer: Lesions formed on healthy sea urchins only if the external epithelium was mechanically abraded before transfer (Table 2). All 5 of the healthy, mechanically abraded individuals developed a lesion within $24 \mathrm{~h}$. The appearance of experimentally induced lesions was similar to that of naturally occurring lesions and followed a similar progression, including spine loss, necrosis of tissue, presence of microorganisms, edema, and erosion and denuding of the test. However, none of the urchins with experimentally induced lesions died as a result of disease under these experimental conditions. They recovered with regeneration of spines and other tissues by the end of the 3 mo test period. Little effect was demonstrated on the non-abraded individuals or the control group.

Close contact: Results from the close contact experiment demonstrated a similar requirement for prior wounding (Table3). However, the lesions which de- 
Table 3. Strongylocentrotus purpuratus. Results of close contact between diseased and healthy individuals

\begin{tabular}{|c|c|c|c|c|c|}
\hline \multirow{2}{*}{\multicolumn{2}{|c|}{ Group }} & \multirow{2}{*}{$\begin{array}{l}\text { No. of } \\
\text { urchins }\end{array}$} & \multicolumn{3}{|c|}{ Experimental period } \\
\hline & & & $24 \mathrm{~h}$ & $2 \mathrm{~d}$ & 2 wk \\
\hline \multicolumn{6}{|c|}{ Experimental: 1 of each pair diseased ${ }^{*}$} \\
\hline (1) & $\begin{array}{l}\text { One urchin with lesions, other } \\
\text { urchin with epithelium } \\
\text { mechanically abraded }\end{array}$ & 10 & $\begin{array}{l}\text { Tiny, scattered } \\
\text { lesion formation }\end{array}$ & $\begin{array}{l}\text { Progression similar } \\
\text { to natural lesions }\end{array}$ & $\begin{array}{l}\text { Regeneration of } \\
\text { normal structures }\end{array}$ \\
\hline (2) & $\begin{array}{l}\text { One urchin with lesions, other } \\
\text { urchin with non-abraded } \\
\text { epithelium }\end{array}$ & 10 & No effect & - & - \\
\hline \multicolumn{6}{|c|}{ Control: no diseased urchins in pairs } \\
\hline (3) & $\begin{array}{l}\text { Urchins with epithelium } \\
\text { mechanically abraded }\end{array}$ & 6 & $\begin{array}{l}\text { Small red clot in all } \\
\text { urchins of each pair }\end{array}$ & $\begin{array}{l}\text { Regeneration of } \\
\text { tissues }\end{array}$ & Complete healing \\
\hline (4) & $\begin{array}{l}\text { Urchins with non-abraded } \\
\text { epithelium }\end{array}$ & 6 & No effect & - & - \\
\hline
\end{tabular}

veloped on these mechanically abraded urchins in close contact with diseased urchins were tiny and showed healing by 2 wk. As observed with the lesion transfer urchins, little effect was demonstrated on the non-abraded individuals or the control groups.

Bacterial virulence: Mechanical abrading was again necessary for lesion development after bacterial inoculation. Moreover, the only mechanically abraded urchins which developed characteristic lesions were those inoculated with isolates of Vibrio anguillarum and Aeromonas salmonicida (Fig. 4) indicating that these bacteria are highly infectious when epithelium is mechanically abraded. Bacteria recovered from the experimentally infected sea urchins were confirmed to be $V$. anguillarum and $A$. salmonicida depending on the infecting bacterial strain, thereby fulfilling Koch's postulates. The other isolates were not recovered from the experimentally infected animals and they did not cause lesion development when applied to the wounded surface of the sea urchin.

\section{DISCUSSION}

During this study a low incidence of diseased sea urchins Strongylocentrotus purpuratus was found in healthy populations in the Monterey Bay area, California, as Yellin et al. (1977) reported; the populations observed did not suffer an episode of massive infection and death. Nevertheless, the lesions we found were similar to those which occurred during the massive infections described by Johnson (1971), Pearse et al. (1977), Boudouresque et al. (1981) and Höbaus et al. (1981). Moreover, as found by Maes \& Jangoux (1984, 1985) lesion material was infectious and caused formation of characteristic lesions when transferred. onto abraded surfaces of healthy urchins. Only the isolates of Vibrio anguillarum and Aeromonas salmonicida were virulent for abraded epithelial surfaces of the sea urchins. Because sea urchins did not die as a result of the experimental treatments used in this study, it is possible that the dosage applied was too small or the bacteria were not highly virulent strains. Moreover, because the urchins did not die and the bacteria only affected abraded areas of the test, these bacterial strains may not be the pathogens responsible for observed mass mortalities.

It is well established that species of all 4 genera of bacteria isolated from the lesions (Vibrio, Aeromonas, Flavobacterium, Pseudomonas) are common and found in substantial numbers in the marine environment where they may occur on surfaces of marine animals (Colwell \& Liston 1960, Baumann \& Baumann 1977, Bonde 1977, Unkles 1977, McCarthy \& Roberts 1980, Palleroni 1981, Gilles 1984). Bonde (1977) reported that both Vibrio spp. and Aeromonas spp. are frequently found in sediments and marine waters, even in relatively unpolluted areas. McCarthy \& Roberts (1980) suggested that Aeromonas spp. may contaminate muds or sediments as a result of an epizootic event and survive for considerable periods of time by metabolizing sediments. DiSalvo et al. (1978) documented the presence of large numbers of $V$. anguillarum in the hatchery culture system during a disease outbreak at the Pigeon Point Shellfish Hatchery near the area where some of the diseased sea urchins used in this study were collected.

In a study describing normal bacterial flora of sea urchins, Holland \& Nealson (1978) reported unidentified and apparently non-pathogenic bacteria between cuticle and epidermal cells of Strongylocentrotus purpuratus. They found no evidence that these 
bacteria invaded the cuticle from the outer surface, nor did they find that these bacteria were associated with cuticular lesions. Another study describing normal bacterial flora of sea urchins isolated some 85 strains of bacteria from Echinus esculentus, of which Vibriospp. and Pseudomonas spp. predominated (Unkles 1977). None of these were demonstrated by Unkles to be pathogenic.

Relatively little work has been done on the diseases of echinoderms (Jangoux 1984). Although Maes \& Jangoux $(1984,1985)$ harvested bacteria from lesions on diseased sea urchins and used them for infectivity experiments, they did not isolate or characterize the bacteria. We show that Vibrio and Aeromonas are among the probable etiological agents of lesion formation in sea urchins. The pathogenicity of both Vibrio anguillarum and Aeromonas salmonicida has been well established for many other marine organisms including eels (Bergman 1909); salmon (Scott 1968, Evelyn 1971a, b, Novotny et al. 1975, Harrell et al. 1976, Hahnel \& Gould 1982); oysters (Mackin 1961, Tubiash et al. 1970, Brown \& Losee 1978, DiSalvo et al. 1978, Leibovitz 1979, Elston 1981); shrimp (Lightner \& Lewis 1975); and lobsters (Bowser et al. 1981). Thus, considering the ubiquitous nature and well-known pathogenicity of the vibrios and aeromonads, it is not surprising that they should also be implicated in diseases of sea urchins.

Whether these bacteria are responsible for the reported mass mortalities of sea urchins remains unresolved. In the descriptions of mass mortalities of sea urchins in Nova Scotia, lesions were not found (Scheibling 1984, Jones et al. 1985). Jones et al. (1985) further describe internal destruction of muscles and connective tissue that result in the flaccid tube feet and disheveled spines in individuals in early phases of the mass mortality disease. They suggested that these symptoms may be due to a pathogenic amoeba Paramoeba sp. Lesions, if they form during mass mortality, may only develop after some of the spines are shed and provide substrate for lesion-causing bacteria. Thus, the bacteria could be a secondary event associated with mass mortalities. Similarly, lesions found infrequently on animals in otherwise healthy populations, could be the result of bacterial infections due to superficial damage to the test. Considering the ability of lesioninfected animals to recover, the lesions that we observed may not usually lead to the urchin's death.

Further studies on the role of pathogenic bacteria, amoebas and other agents are needed before the causes of mass mortalities can be established.

Acknowledgements. This work is a result of research sponsored in part by NOAA, National Sea Grant College Program,
Department of Commerce, under grant number NA 80AA-D00120, project number R/CZ-58, through the California Sea Grant College Program. The US Government is authorized to reproduce and distribute for governmental purposes. We gratefully thank Drs Eugene $\mathrm{H}$. Cota-Robles and Ralph $\mathrm{T}$. Hinegardner for their continued assistance and encouragement, and 2 alert anonymous reviewers for constructive criticism. We also thank M. Jangoux for kindly providing us with manuscripts 'in press'

\section{LITERATURE CITED}

Allen, R. D., Baumann, P. (1971). Structure and arrangement of flagella in species of the genus Beneckea and Photobacterium fischeri. J. Bacteriol. 107: 295-302

Baumann, P., Baumann, L. (1977). Biology of the marine enterobacteria: Genera Beneckea and Photobacterium. Ann. Rev. Microbiol. 31: 39-61

Bergman, A. M. (1909). Die rote Beulenkrankheit des Aals. Ber. Kgl. Bayer. Biol. Verssta. 2: 10-54

Bonde, G. J. (1977). Bacterial indication of water pollution. In: Droop, M. R., Jannasch, H. W. (ed.) Advances in aquatic microbiology, Vol. 1. Academic Press, New York, p. $273-364$

Boudouresque, C. F., Nedelec, H., Shepherd, S. A. (1981). The decline of a population of the sea urchin Paracentrotus lividus in the Bay of Port-Cros (Var, France). Rapp. Comm. Int. Mer Medit. 27: 223-234

Bowser, P. R., Rosemark, R., Reiner, C. R. (1981). A preliminary report of vibriosis in cultured american lobsters, Homarus americus. J. Invertebr. Pathol. 37: 80-85

Bradshaw, L. J. (1973). Laboratory microbiology, 2nd ed. W. B. Saunders Co., Philadelphia

Brown, C., Losee, E. (1978). Observations on natural and induced epizootics of vibriosis in Crassostrea virginica larvae. J. Invertebr. Pathol. 31: 41-47

Chow, M. S., Rouf, M. A. (1983). Isolation and partial characterization of two Aeromonas hydrophilia bacteriophages. Appl. environ. Microbiol. 45: 1670-1676

Colwell, R. R., Liston, J. (1960). Microbiology of shellfish Bacteriological study of the natural flora of Pacific oysters (Crassostrea gigas). Appl. Microbiol. 8: 104-109

DiSalvo, L. H., Blecka, J., Zebal, R. (1978). Vibrio anguillarum and larval mortality in a California coastal shellfish hatchery. Appl. environ. Microbiol. 35: 219-221

Elston, R. (1981). New ultrastructural aspects of a serious disease of hatchery reared larval oysters. J. Fish Dis. 3 $1-10$

Evelyn, T. P. T. (1971a). First records of vibriosis in Pacific salmon cultured in Canada, and taxonomic status of the responsible bacteria Vibrio anguillarum. J. Fish. Res. Bd Can. 28: 517-525

Evelyn, T. P. T. (1971b). An aberrant strain of the bacterial fish pathogen Aeromonas salmonicida isolated from a marine host, the sablefish (Anoplopoma fimbris) and from two species of cultured Pacific salmon. J. Fish. Res. Bd Can. 28: 1629-1634

Furniss, A. L., Lee, J. V., Donovan, T. J. (1978). The vibrios. Public Health Laboratory Services, Monograph Series 11, Her Majesty's Stationery Office, London

Gerhardt, P., Murray, R. G. E., Costilow, R. N., Nester, E. W. Wood, W. A., Krieg, N. R., Phillips, G. B. (1981). Manual of methods for general bacteriology. Am. Soc. Microbiol., Wash., D.C.

Gilles, K. W. (1984). Biochemical characterization and 
pathogenic evaluation of bacteria found in association with marine invertebrates. Ph.D. thesis, University of California, Santa Cruz

Hahnel, G. B., Gould, R. W. (1982). Effects of temperature on biochemical reactions and drug resistance of virulent and avirulent Aeromonas salmonicida. J. Fish Dis. 5: 329-337

Harrell, L. W., Novotny, A. J., Schiewe, M. H., Hodgins, H. O. (1976). Isolation and description of 2 vibrios pathogenic to Pacific salmon in Puget sound, Washington. Fish. Bull. U.S. 74: $447-449$

Höbaus, E. (1979). Skin excretion in sea urchins. Naturwissenschaften 66: 160-161

Höbaus, E., Fenaux, L., Hignette, M. (1981). Premières observations sur les lesions provoquées par une maladie affectant le test des oursins en Méditerranée occidentale. Rapp. P.-v. Réun. Commn int. Explor. scient. Mer Méditerr. 27 : 221-222

Holland, N. D., Nealson, K. H. (1978). The fine structure of the echinoderm cuticle and the subcuticular bacteria of echinoderms. Acta zool. Stockh. 59: 169-185

Jangoux, M. (1984). Diseases of echinoderms. Helgoländer Meeresunters. 37: 207-216

Johnson, P. T. (1971). Studies on diseased urchins from Pt. Loma. In: North, W. J. (ed.) Kelp habitat improvement project, annual report 1970-1971. California Institute of Technology, Pasadena, p. 82-90

Jones, G. M., Hebda, A. J., Scheibling, R. E., Miller, R. J. (1985). Histopathology of the disease causing mass mortality of sea urchins (Strongylocentrotus droebachiensis) in Nova Scotia. J. Invertebr. Pathol. 45: 260-271

Koga, T., Toyoshima, S., Kawata, T. (1982). Morphological varieties and host ranges of Vibrio parahaemolyticus bacteriophages isolated from sea water. Appl. environ. Microbiol. 44: 466-470

Kovacs, N. (1956). Identification of Pseudomonas pyocyanea by the oxidase reaction. Nature, Lond. 178: 703

Lara, J. C. (1970). The infectious process of a unique lipidcontaining bacterial virus: Bacteriophage PM2. Ph.D. dissertation, Univ. of California, Riverside

Lear, D. W. (1963). Occurrence and significance of chitinoclastic bacteria in pelagic waters and zooplankton. In: Oppenheimer, C. H. (ed.) Symposium on marine microbiology. C. C. Thomas, Springfield, Ill., p. 594-610

Leibovitz, L. (1979). A study of vibriosis at a Long Island shellfish hatchery. New York Sea Grant Reprint Series. NYSG-RR-79-02. N.Y. Sea Grant Inst. Albany, New York

Lessios, H. A., Glynn, P. W., Robertson, D. R. (1983). Mass mortalities of coral reef organisms. Science 222: 714

Lessios, H. A., Robertson, D. R., Cubit, J. D. (1984a). Spread of Diadema mass mortality through the Caribbean. Science 226: 335-337

Lessios, H. A., Cubit, J. D., Robertson, D. R., Shulman, M. J., Parker, M. R., Garrity, S. D., Levings, S. C. (1984b). Mass mortality of Diadema antillarum on the Caribbean coast of Panama. Coral Reefs 3: 173-182

Lightner, D. V., Lewis, D. H. (1975). A septicemic bacterial disease syndrome of penaeid shrimp. Mar. Fish. Rev. 37 : 25-28

McCarthy, D. H., Roberts, R. J. (1980). Furunculosis of fish. The present state of our knowledge. In: Droop, M. R., Jannasch, H. W. (ed.) Advances in aquatic microbiology, Vol. 2. Academic Press, New York, p. 293-341

MacDonell, M. T., Singleton, F. L., Hood, M. A. (1982). Diluent composition for use of API 20E in characterizing marine and estuarine bacteria. Appl. environ. Microbiol. $44: 423-427$
Mackin, J. G. (1961). Mortalities of oysters. Proc. Natl. Shellf. Ass. 50: $21-40$

Maes, P., Jangoux, M. (1984). The bald-sea-urchin disease: a biopathological approach. Helgoländer Meeresunters. 37: $217-224$

Maes, P., Jangoux M. (1985). The bald-sea-urchin disease: a bacterial disease. In: Keegan, B. F. (ed.) Proc. 5th Inter. Conf. Echinoderm, Galway (in press)

Maes, P., Jangoux, M., Fenaux, L. (1985). La maladie de l'oursin-chauve': Ultrastructure des lesions et caracterisation de leur pigmentation. Annls. Inst. océanogr., Paris.

Mayfield, C. I., Inniss, W. E. (1977). A rapid, simple method for staining bacterial flagella. Can. J. Microbiol. 23: $1311-1313$

Miller, R. J. (1985). Sea urchin pathogen: a possible tool for biological control. Mar. Ecol. Prog. Ser. 21: 169-174

Miller, R. J., Colodey, A. G. (1983). Widespread mass mortalities of the green sea urchin in Nova Scotia, Canada. Mar. Biol. 73: 263-267

Mortensen, T., Rosevinge, L. K. (1934). Sur une algue cyanophycee, Dactylococcopsis echini n. sp., parasite dans un oursin. Biol. Meddr. 11: 1-10

Novotny, A. J., Harrel, L. W., Nyegaard, C. W. (1975). Vibriosis, a common disease of Pacific salmon cultured in marine waters of Washington. Wash. State Univ. Pullman Wash. Coll. Agric., Coop. Ext. Serv., Ext. Bull. 663: 1-8

Palleroni, N. J. (1981). Introduction to the family Pseudomonadaceae. In: Starr, M. P., Stolp, H., Truper, H. G. Balows, A., Schlegel, H. G. (ed.) The prokaryotes: a handbook on habitats, isolation and identification of bacteria. Springer-Verlag, Berlin, p. 655-665

Pearse, J. S., Costa, D. P., Yellin, M. B., Agegian, C. R. (1977). Localized mass mortality of red sea urchin, Strongylocentrotus franciscanus, near Santa Cruz, California. Fish. Bull. U.S. 75: 645-648

Ruby, E. G., Nealson, K. H. (1978). Seasonal changes in the species composition of luminous bacteria in nearshore seawater. Limnol. Oceanogr. 23: 530-533

Sakazake, R., Balows, A. (1981). The genera Vibrio, Plesiomonas and Aeromonas. In: Starr, M. P., Stolp, H., Truper, H. G., Balows, A., Schlegel, H. G. (ed.) The prokaryotes: a handbook on habitats, isolation and identification of bacteria. Springer-Verlag, Berlin, p. 1272-1301

Scheibling, R. E. (1984). Echinoids, epizootics and ecological stability in the rocky subtidal off Nova Scotia, Canada. Helgoländer Meeresunters. 37: 233-242

Scheibling, R. E., Stephenson, R. L. (1984). Mass mortality of Strongylocentrotus droebachiensis (Echinodermata: Echinoidea) off Nova Scotia, Canada. Mar. Biol. 78: 153-164

Scott, M. (1968). The pathogenicity of Aeromonas salmonicida (Griffin) in sea and brackish waters. J. gen. Microbiol. 50: 321-327

Sizemore, R. K., Stevenson, L. H. (1970). Method for the isolation of proteolytic marine bacteria. Appl. Microbiol. 20: 991-992

Tubiash, H. S., Colwell, R. R., Sakazake, R. (1970). Marine vibrios associated with bacillary necrosis, a disease of larval and juvenile bivalve molluscs. J. Bacteriol. 103: 272-273

Unkles, S. E. (1977). Bacterial flora of the sea urchin Echinus esculentus. Appl. environ. Microbiol. 34: 347-350

Yellin, M. B., Agegian, C. R., Pearse, J. S. (1977). Ecological benchmarks in the Santa Cruz county kelp forests before the re-establishment of sea otters. Center for Coastal Marine Studies, Univ. of Calif. Technical Report No. 6: $1-125$ 